\title{
ACETABULOPLASTY IN THE TREATMENT OF CONGENITAL DISLOCATION OF THE HIP
}

\author{
D. Trevor, D. L. Johns and J. A. Fixsen, London, England \\ From the Royal National Orthopaedic Hospital, London and Stanmore, and St Bartholomew's Hospital, London
}

The results in 102 acetabuloplasties have been assessed in eighty-six patients, with a minimum follow-up of five years. Clinical and radiological assessment was carried out according to a score system very similar to that used in previous studies, and the results were expressed as excellent, good, fair and poor according to the score obtained. Any hip requiring further stabilising procedures was automatically grouped as a failure. Subtrochanteric femoral osteotomy was used when femoral anteversion was excessive. The results revealed that 73 per cent of the hips were satisfactory (excellent or good) overall, but that a steady deterioration was evident when the five- and fifteen-year groups were compared. Few of the hips were regarded as normal on radiological grounds. Homologous bone bank rib was found to be the most satisfactory graft material. Coxa magna was the most common abnormality that was consistent with a good or excellent result. Avascular necrosis of the femoral head was found in only six hips; it was more commonly present in patients subjected to previous operation. Concentric reduction of the femoral head is essential if acetabuloplasty is to maintain stability of the hip.

Acetabuloplasty in various forms has for many years been used to achieve joint stability in congenital dislocation, subluxation and dysplasia of the hip. One of us (D. T.) has used the procedure ascribed to A. O. Parker (unpublished) of Cardiff for this purpose over a period of twenty-five years. This survey presents the results achieved and the problems encountered in its use.

\section{MATERIAL}

Ninety-four patients have been reviewed with a minimum follow-up of five years from the time of operation. Seven patients were excluded from the survey because of

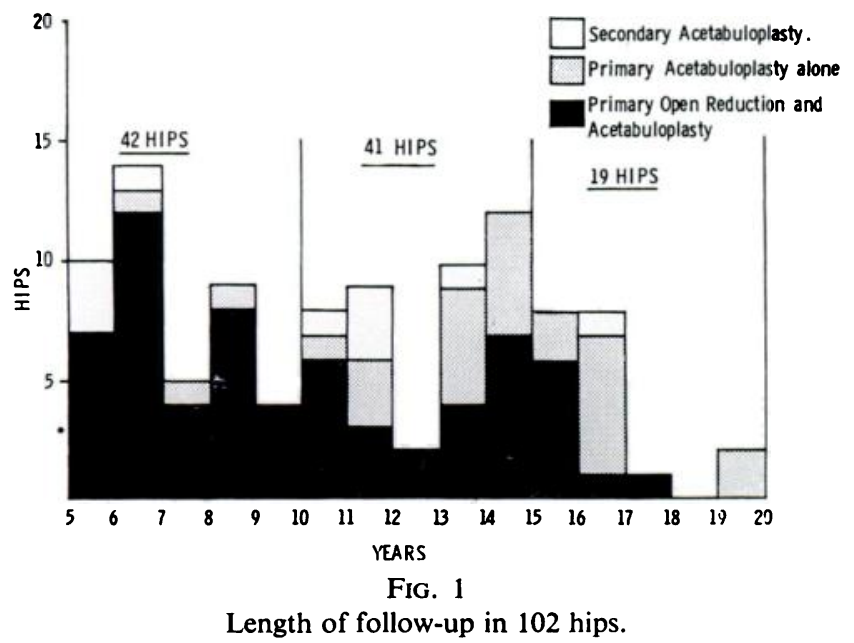

inadequate radiographs or incomplete records, or because their hip condition was secondary to other conditions such as arthrogryposis multiplex congenita. Eighty-six patients remained in whom 102 acetabuloplasties were performed (Fig. 1). Eighteen patients were male and sixty-eight female. Sixty-one patients were treated primarily at the Royal National Orthopaedic Hospital and twenty-five were referred from elsewhere after previous conservative or operative measures (Table I). Only four patients (six hips) had no form of closed or

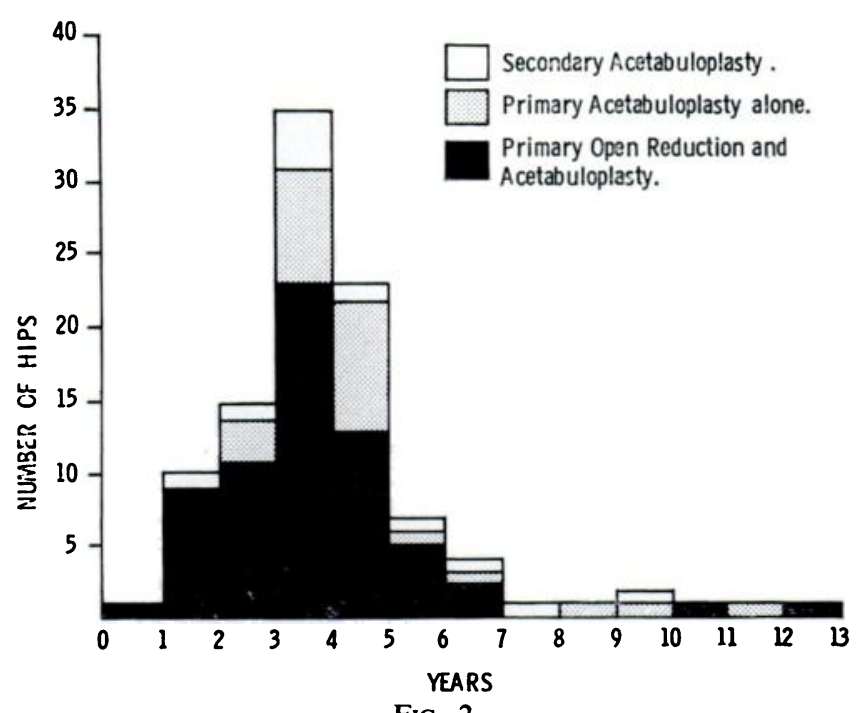

FiG. 2

Age at operation in 102 hips.

D. Trevor, M.S., F.R.C.S., Gardens, Gustard Wood, Wheathampstead, Hertfordshire, England.

D. L. Johns, F.R.C.S., Consultant Orthopaedic Surgeon, Peterborough District Hospital, Peterborough, England.

J. A. Fixsen, M.Chir., F.R.C.S., Consultant Orthopaedic Surgeon, Hospital for Sick Children, Great Ormond Street, London WC1N 3JH, England. 
operative treatment before the acetabuloplasty. Treat- the displacement in fifty-five patients (sixty-five hips). It ment in the remaining eighty-two varied from simple skin was performed alone as the primary stabilising procedure traction to multiple closed and operative procedures. The in twenty-three patients (twenty-seven hips), all of whom

TABLE I

Clinical Material

\begin{tabular}{|c|c|c|c|c|c|c|}
\hline $\begin{array}{c}\begin{array}{c}\text { Number } \\
\text { of } \\
\text { patients }\end{array}\end{array}$ & Operation & $\begin{array}{l}\text { Number } \\
\text { of hips }\end{array}$ & Male & Female & $\begin{array}{c}\underset{\text { Primary }}{\text { treatment }} \\
\text { at R.N.O.H.* }\end{array}$ & $\begin{array}{l}\text { Primary } \\
\text { treatment } \\
\text { elsewhere }\end{array}$ \\
\hline 55 & $\begin{array}{l}\text { Primary open } \\
\text { reduction and } \\
\text { acetabuloplasty }\end{array}$ & 65 & 13 & 42 & 38 & 17 \\
\hline 23 & $\begin{array}{l}\text { Primary } \\
\text { acetabuloplasty } \\
\text { alone }\end{array}$ & 27 & 4 & 19 & 18 & 5 \\
\hline 8 & $\begin{array}{l}\text { Secondary } \\
\text { acetabuloplasty }\end{array}$ & 10 & 1 & 7 & 5 & 3 \\
\hline 86 & & 102 & 18 & 68 & 61 & 25 \\
\hline
\end{tabular}

* R.N.O.H. $=$ Royal National Orthopaedic Hospital.

TABLE II

TYPE OF OPERATION AND OF Disorder OF HiP

\begin{tabular}{|c|c|c|c|c|}
\hline Operation & $\begin{array}{c}\text { Number of } \\
\text { hips }\end{array}$ & Dislocation & $\begin{array}{l}\text { Diagnosis } \\
\text { Subluxation }\end{array}$ & Dysplasia \\
\hline $\begin{array}{l}\text { Open reduction } \\
\text { and } \\
\text { acetabuloplasty }\end{array}$ & 65 & 59 & 6 & 0 \\
\hline $\begin{array}{l}\text { Primary } \\
\text { acetabuloplasty } \\
\text { alone }\end{array}$ & 27 & 20 & 5 & 2 \\
\hline \multirow[t]{2}{*}{$\begin{array}{l}\text { Secondary } \\
\text { acetabuloplasty }\end{array}$} & 10 & 9 & 1 & 0 \\
\hline & 102 & 88 & 12 & 2 \\
\hline
\end{tabular}

TABLE III

UPPER FEMORAL OSTEOTOMY

\begin{tabular}{|c|c|c|c|c|c|}
\hline Operation & $\begin{array}{c}\text { Number } \\
\text { of hips }\end{array}$ & $\begin{array}{l}\text { Osteotomy at } \\
\text { the time of } \\
\text { acetabuloplasty }\end{array}$ & $\begin{array}{l}\text { Osteotomy } \\
\text { later }\end{array}$ & $\begin{array}{l}\text { Osteotomy } \\
\text { repeated }\end{array}$ & $\begin{array}{c}\text { No } \\
\text { osteotomy }\end{array}$ \\
\hline $\begin{array}{l}\text { Open reduction } \\
\text { and } \\
\text { acetabuloplasty }\end{array}$ & 65 & 19 & 41 & $5(\times 2$ in one patient $)$ & 0 \\
\hline $\begin{array}{l}\text { Primary } \\
\text { acetabuloplasty }\end{array}$ & 27 & 2 & 12 & $4(\times 2$ in one patient) & 9 \\
\hline \multirow[t]{2}{*}{$\begin{array}{l}\text { Secondary } \\
\text { acetabuloplasty }\end{array}$} & 10 & 2 & 3 & 2 & 3 \\
\hline & 102 & 23 & 56 & 11 & 12 \\
\hline
\end{tabular}

age at operation varied from nine months to twelve years, had had a previous period of conservative treatment. In with an average of four years and two months (Fig. 2). eight patients (ten hips) it was undertaken as a secondary Acetabuloplasty was combined with open reduction of procedure, combined with open reduction in four hips 
after failure of earlier operation to give joint stability (Table II). Upper femoral osteotomy to correct valgus or rotational deformity was performed at the same time as acetabuloplasty in twenty-three hips, and at a later date in fifty-six hips. It was repeated in eleven hips (Table III). The bone graft material for the acetabuloplasty was taken from the patient's own ilium in forty hips, homologous bone bank rib was used in fifty-eight hips and a combination of the two in four hips (Table IV).

TABLE IV

TYPE OF GRAFT

\begin{tabular}{|c|c|c|c|c|}
\hline Operation & $\begin{array}{l}\text { Number } \\
\text { of hips }\end{array}$ & $\begin{array}{l}\text { Autologous } \\
\text { iliac bone }\end{array}$ & $\begin{array}{c}\text { Homologous } \\
\text { bone bank } \\
\text { rib }\end{array}$ & $\begin{array}{l}\text { Combination } \\
\text { of autologous } \\
\text { iliac bone and } \\
\text { homologous } \\
\text { bone bank rib }\end{array}$ \\
\hline $\begin{array}{l}\text { Primary open } \\
\text { reduction and } \\
\text { acetabuloplasty }\end{array}$ & 65 & 19 & 45 & 1 \\
\hline $\begin{array}{l}\text { Primary } \\
\text { acetabuloplasty } \\
\text { alone }\end{array}$ & 27 & 17 & 7 & 3 \\
\hline \multirow[t]{2}{*}{$\begin{array}{l}\text { Secondary } \\
\text { acetabuloplasty }\end{array}$} & 10 & 4 & 6 & 0 \\
\hline & 102 & 40 & 58 & 4 \\
\hline
\end{tabular}

Open reduction and acetabuloplasty were performed for dislocation in fifty-nine hips and for subluxation in six hips. Acetabuloplasty alone was performed for dislocation in twenty hips, for subluxation in five and for dysplasia in two. Acetabuloplasty as a secondary procedure was performed for dislocation in nine hips and for subluxation in one.

Acetabuloplasty is indicated when a concentrically reduced hip moves, or in all probability will move, into an eccentric position with resultant redisplacement due to a sloping lateral portion of a shallow acetabulum. A defective anterior part of the acetabulum which allows forward redisplacement should be corrected by innominate osteotomy. How to determine which type of operative procedure is required has been described by one of us (Trevor 1972). In congenital dislocation the hip will develop normally only if the femoral head is reduced concentrically and kept in that position for a sufficient length of time. Even with concentric reduction development may occasionally be defective because of genetic factors affecting acetabular growth. In such instances an eccentric position results. Defective growth may affect different parts of the acetabulum, and treatment must be adjusted accordingly. If the anterior part of the socket is affected a type of innominate osteotomy is needed-an acetabuloplasty in such circumstances is exceedingly difficult and the result is disappointing. When the development of the lateral portion of the acetabulum is defective so that a sloping lateral roof is produced, acetabuloplasty is necessary to obliterate the space between the roof and the femoral head. This then is the main indication for the operation, whether the reduction of the subluxation or dislocation has been effected by closed means or by operation. It is very rarely necessary in children under two years old; it becomes more often indicated as the age of those treated increases, and in children approaching puberty again becomes rarely necessary. Any excessive anteversion (40 degrees or more) and valgus deformity (20 degrees or more) associated with a sloping acetabular roof must be corrected. Valgus deformity must be corrected immediately before acetabuloplasty, otherwise the femoral head will remain eccentric in the socket, causing abnormal pressure on the newly constructed lateral roof and hindering normal development of the acetabular roof.

\section{TECHNIQUE OF ACETABULOPLASTY}

The anaesthetised patient lies supine, a small pillow beneath the buttock elevating the affected hip. The skin incision extends just lateral but parallel to the anterior half of the iliac crest. It then passes down the thigh to a point just distal to the inferior iliac spine. If the hip joint remains dislocated a standard Smith-Petersen (1949) anterior approach is used. The interval between the sartorius muscle and the tensor fasciae latae is next

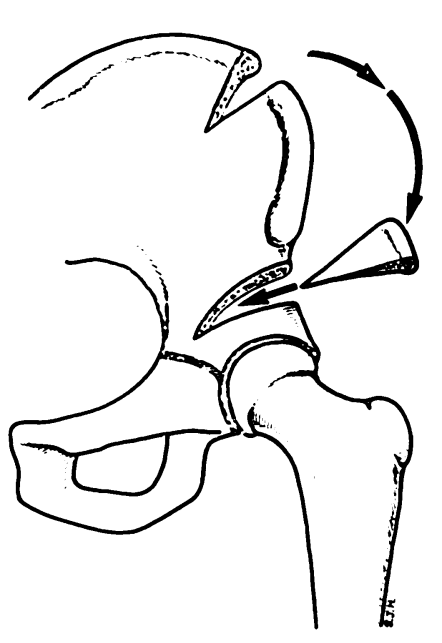

FIG. 3

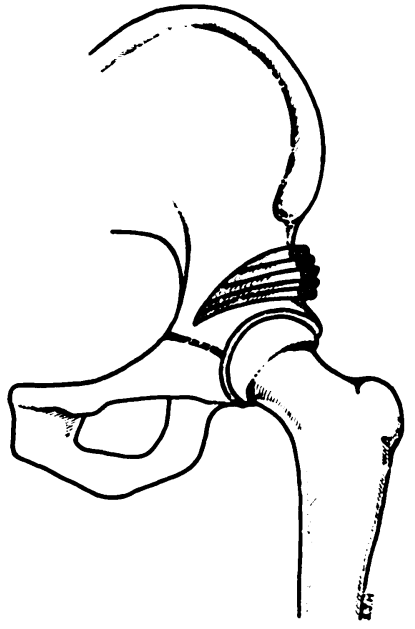

Fig. 4
Figure 3-Diagram showing wedge iliac bone graft. Figure 4Diagram showing use of bone bank rib grafts.

defined, care being taken to preserve the lateral cutaneous nerve of the thigh. The iliac apophysis is split longitudinally along the exposed length, including that over the superior iliac spine. Subperiosteal reflection of the gluteus medius and minimus and of the tensor fasciae latae is performed to expose the rectus femoris lying on the hip joint capsule. The reflected head of the muscle will require division to expose the superior and superoposterior aspects of the capsule. The straight head may be spared provided it can be retracted to allow sufficient exposure of the anterior aspect of the joint capsule. 
If the acetabuloplasty is needed for a hip reduced by closed methods the level of the acetabular roof is determined either with a long strong needle inserted at different levels or by inserting a guide wire so that its position and direction can be seen on a radiograph. If in spite of these methods doubt still exists, a small opening in the capsule should allow the roof level to be seen. If open reduction is necessary there is no difficulty in determining the level of the roof.

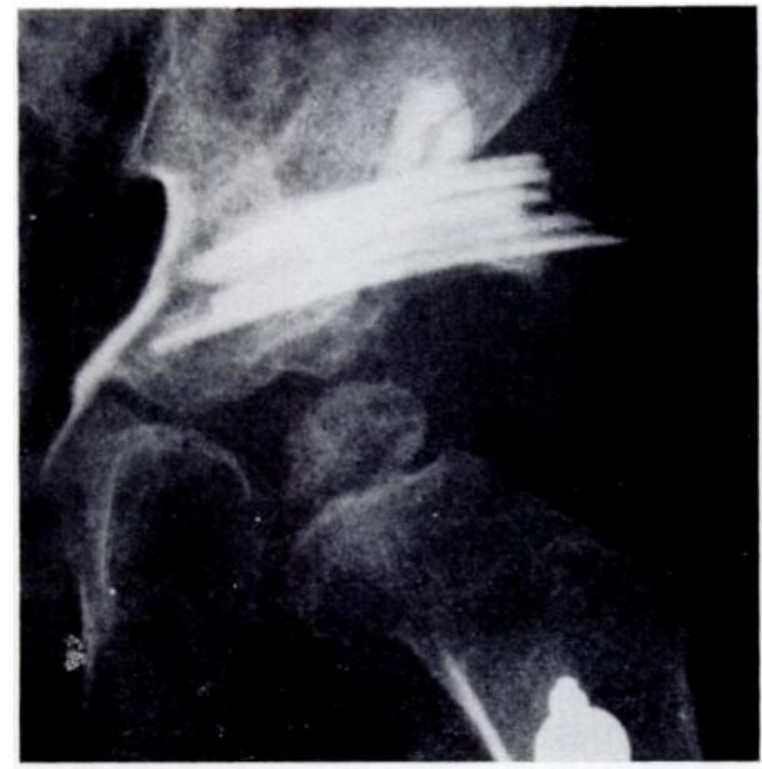

Fig. 5

Radiograph after acetabuloplasty showing "timber-stack" grafts in place.

A thin portion of ilium bearing the outer cortex is turned down to extend over the joint capsule. It starts two centimetres above the roof level and extends from the anterior to the posterior aspect of the hip in a slightly upward curved fashion. At a point about 4 millimetres above the roof an osteotome is directed inwards, front and back, parallel to the roof as far as the triradiate cartilage. This loosens that portion of the ilium bearing the lateral part of the acetabulum, which is levered downwards to cover the femoral head firmly, the joint capsule intervening. This creates a gap above the roof which is then firmly filled with bone. Either an adequate iliac wedge bone graft is slotted into a prepared groove in the proximal edge of the gap to prevent twisting of the graft, the rest of the gap being filled with iliac chips (Fig. 3 ), or bone bank ribs split longitudinally into suitable lengths are packed into the gap in layers like a timber stack (Figs. 4 and 5). The gap must be packed firmly so that a forcible upward thrust of the limb causes no displacement of the femoral head. The turned down flap of cortical bone should then be anchored to the capsule by two or three stitches.

The wound is closed in layers without drainage, careful haemostasis having been secured. A radiograph
TABLE $\mathrm{V}$

METHOD OF ASSESSMENT

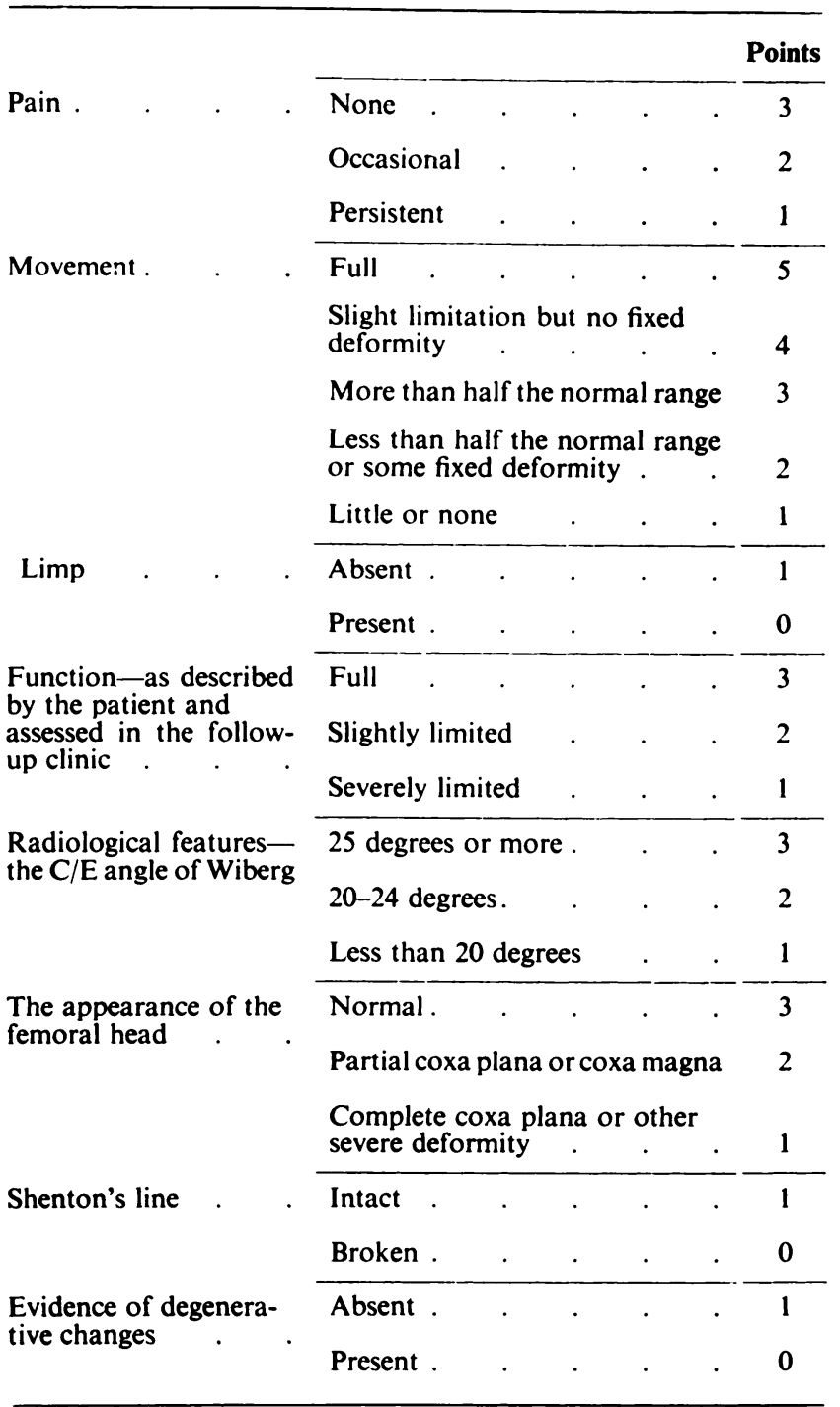

TABLE VI

RESULTS

\begin{tabular}{|c|c|c|c|c|c|}
\hline \multirow[b]{3}{*}{ Operation } & \multirow[b]{3}{*}{$\begin{array}{l}\text { Number } \\
\text { of hips }\end{array}$} & \multicolumn{4}{|c|}{ Results } \\
\hline & & \multicolumn{2}{|c|}{ Satisfactory } & \multicolumn{2}{|c|}{ Unsatisfactory } \\
\hline & & $\begin{array}{c}\text { Excellent } \\
(18-20 \\
\text { points })\end{array}$ & $\begin{array}{l}\text { Good } \\
\text { (15-17 } \\
\text { points) }\end{array}$ & $\begin{array}{l}\text { Fair } \\
\text { (12-14 } \\
\text { points) }\end{array}$ & $\begin{array}{c}\text { Poor } \\
\text { (less than } \\
12 \text { points) }\end{array}$ \\
\hline $\begin{array}{l}\text { Primary open } \\
\text { reduction and } \\
\text { acetabuloplasty }\end{array}$ & 65 & 20 & 30 & 10 & 5 \\
\hline $\begin{array}{l}\text { Primary } \\
\text { acetabuloplasty } \\
\text { alone }\end{array}$ & 27 & 9 & 9 & 7 & 2 \\
\hline \multirow[t]{3}{*}{$\begin{array}{l}\text { Secondary } \\
\text { acetabuloplasty }\end{array}$} & 10 & 2 & 5 & 2 & 1 \\
\hline & 102 & 31 & 44 & 19 & 8 \\
\hline & & \multicolumn{2}{|c|}{$\begin{array}{c}75 \\
\text { (73.5 per cent) }\end{array}$} & \multicolumn{2}{|c|}{$\stackrel{27}{(26 \cdot 5 \text { per cent })}$} \\
\hline
\end{tabular}


is taken to check the position of the femoral head and the acetabular roof. If the appearance is satisfactory, a padded full plaster hip spica is applied, the opposite limb being included as far as the knee. In children under five years of age, six weeks' immobilisation is sufficient, but over five years a further two or three weeks are advisable.

Occasionally acetabuloplasty is needed when in addition an increase of valgus deformity of the femoral neck exists. If the deformity is of a minor nature the formation of a well-fitting acetabular roof will be sufficient. If, however, the valgus deformity is excessive, a subtrochanteric femoral wedge osteotomy is necessary and should be done immediately before but at the same operation as the acetabuloplasty. Anteversion deformity (with or without minor valgus deformity) may be corrected by femoral osteotomy at the time of the acetabuloplasty or delayed until three weeks later.
ASSESSMENT

The patients were either seen and assessed in the senior author's follow-up clinic or, if they had not been seen for more than two years, they attended a special clinic arranged for this survey. The patients were assessed at follow-up both clinically and radiologically. The results were recorded by a points system which is a modification of that described by MacKenzie, Seddon and Trevor (1960) (Table V).

The maximum score on this system is 20 points and the minimum 5. Hips with a score of $18-20$ points were considered excellent, 15-17 good, 12-14 fair and below 12 poor. If a patient required further stabilising procedures the operation was automatically considered a failure. The excellent and good results were grouped together as satisfactory while the fair and poor were considered unsatisfactory.

TABLE VII

Results Related to Duration of Follow-up

\begin{tabular}{|c|c|c|c|c|c|c|c|c|c|c|c|c|}
\hline \multirow[b]{2}{*}{ Operation } & \multirow[b]{2}{*}{$\begin{array}{c}\text { Number } \\
\text { of hips }\end{array}$} & \multicolumn{3}{|c|}{$5-10$ years } & \multicolumn{4}{|c|}{$10-15$ years } & \multicolumn{4}{|c|}{15 years and over } \\
\hline & & \multicolumn{2}{|c|}{$\begin{array}{c}\text { Satisfactory } \\
(\mathbf{E}+\mathbf{G})^{*}\end{array}$} & $\begin{array}{c}\text { Unsatisfactory } \\
(\mathbf{F}+\mathbf{P}) \dagger\end{array}$ & \multicolumn{2}{|c|}{$\begin{array}{l}\text { Satisfactory } \\
(\mathbf{E}+\mathbf{G})\end{array}$} & \multicolumn{2}{|c|}{$\begin{array}{c}\text { Unsatisfactory } \\
(\mathbf{F}+\mathbf{P})\end{array}$} & \multicolumn{2}{|c|}{$\begin{array}{c}\text { Satisfactory } \\
(\mathbf{E}+\mathbf{G})\end{array}$} & \multicolumn{2}{|c|}{$\begin{array}{c}\text { Unsatisfactory } \\
(\mathbf{F}+\mathbf{P})\end{array}$} \\
\hline $\begin{array}{l}\text { Primary open } \\
\text { reduction and } \\
\text { acetabuloplasty }\end{array}$ & 65 & 31 & $\begin{array}{l}E=12 \\
G=19\end{array}$ & $4 \begin{array}{l}F=3 \\
P=1\end{array}$ & 15 & $\begin{array}{l}E=8 \\
G=7\end{array}$ & 8 & $\begin{array}{l}F=4 \\
P=4\end{array}$ & 4 & $\begin{array}{l}E=0 \\
G=4\end{array}$ & 3 & $\begin{array}{l}F=3 \\
P=0\end{array}$ \\
\hline $\begin{array}{l}\text { Primary } \\
\text { acetabuloplasty } \\
\text { alone }\end{array}$ & 27 & 3 & $\begin{array}{l}E=1 \\
G=2\end{array}$ & 0 & 9 & $\begin{array}{l}E=3 \\
G=6\end{array}$ & 4 & $\begin{array}{l}F=4 \\
P=0\end{array}$ & 6 & $\begin{array}{l}E=5 \\
G=1\end{array}$ & 5 & $\begin{array}{l}F=3 \\
P=2\end{array}$ \\
\hline $\begin{array}{l}\text { Secondary } \\
\text { acetabuloplasty }\end{array}$ & 10 & 4 & $\begin{array}{l}E=0 \\
G=4\end{array}$ & 0 & 2 & $\begin{array}{l}\mathrm{E}=\mathbf{2} \\
\mathbf{G}=\mathbf{0}\end{array}$ & 3 & $\begin{array}{l}F=2 \\
P=1\end{array}$ & 1 & $\begin{array}{l}E=0 \\
G=1\end{array}$ & 0 & \\
\hline & 102 & $\begin{array}{l}38 \\
(90\end{array}$ & 4 per cent) & $\begin{array}{l}4 \\
\text { ( } 9 \cdot 6 \text { per cent) }\end{array}$ & $\begin{array}{l}26 \\
(63\end{array}$ & 4 per cent) & $\begin{array}{l}15 \\
(36 \cdot 6\end{array}$ & 6 per cent) & & 9 per cent) & $\begin{array}{c}8 \\
(42 .\end{array}$ & 1 per cent) \\
\hline
\end{tabular}

$* E+G=$ Excellent + good. $\quad+F+P=F a i r+$ poor

TABLE VIII

Results Related to Age at Operation

\begin{tabular}{|c|c|c|c|c|c|c|}
\hline \multirow[b]{3}{*}{ Operation } & \multirow[b]{3}{*}{$\begin{array}{l}\text { Number } \\
\text { of hips }\end{array}$} & \multicolumn{4}{|c|}{ Result } & \multirow[b]{3}{*}{ Overall average age } \\
\hline & & \multicolumn{2}{|c|}{ Satisfactory } & \multicolumn{2}{|c|}{ Unsatisfactory } & \\
\hline & & $\begin{array}{l}\text { Excellent } \\
(18-20)\end{array}$ & $\begin{array}{c}\text { Good } \\
(15-17)\end{array}$ & $\underset{(12-14)}{\text { Fair }}$ & $\begin{array}{l}\text { Poor } \\
\text { (less than 12) }\end{array}$ & \\
\hline $\begin{array}{l}\text { Primary open } \\
\text { reduction and } \\
\text { acetabuloplasty }\end{array}$ & 65 & 3 years 3 months & 3 years 10 months & 3 years 6 months & 3 years 7 months & 3 years $6 \frac{1}{2}$ months \\
\hline $\begin{array}{l}\text { Primary } \\
\text { acetabuloplasty } \\
\text { alone }\end{array}$ & 27 & 3 years 9 months & 5 years 10 months & 4 years 6 months & 4 years 3 months & 4 years 7 months \\
\hline \multirow[t]{2}{*}{$\begin{array}{l}\text { Secondary } \\
\text { acetabuloplasty }\end{array}$} & 10 & 4 years 10 months & 5 years & 4 years 7 months & 3 years 6 months & 4 years 6 months \\
\hline & 102 & 3 years 11 months & 4 years 10 months & 4 years 2 months & 3 years 9 months & 4 years 2 months \\
\hline
\end{tabular}




\section{RESULTS}

The results are shown in Tables VI to $X$.

Seventy-five hips $(73.5$ per cent) were satisfactory and twenty-seven $(26.5$ per cent) were unsatisfactory (Table VI). When the results were related to length of follow-up thirty-eight hips ( 90 per cent) were satisfactory in the five to ten year group, twenty-six (63 per cent) in the ten to fifteen year group and eleven ( 58 per cent) in the over fifteen year group (Table VII). With regard to the average age at operation, there was no apparent difference

TABLE IX

Results Related to Type of Operation

\begin{tabular}{|c|c|c|c|}
\hline \multirow[b]{2}{*}{ Operation } & \multirow[b]{2}{*}{$\begin{array}{l}\text { Number } \\
\text { of hips }\end{array}$} & \multicolumn{2}{|c|}{ Results } \\
\hline & & $\begin{array}{c}\text { Satisfactory } \\
\text { (Excellent and Good) }\end{array}$ & $\begin{array}{c}\text { Unsatisfactory } \\
\text { (Fair and Poor) }\end{array}$ \\
\hline $\begin{array}{l}\text { Primary open } \\
\text { reduction and } \\
\text { acetabuloplasty }\end{array}$ & 65 & $50(76.9$ per cent $)$ & $15(23 \cdot 1$ per cent $)$ \\
\hline $\begin{array}{l}\text { Primary } \\
\text { acetabuloplasty }\end{array}$ & 27 & $18(66.6$ per cent $)$ & $9(33.4$ per cent $)$ \\
\hline \multirow[t]{2}{*}{$\begin{array}{l}\text { Secondary } \\
\text { acetabuloplasty }\end{array}$} & 10 & 7 (70 per cent) & 3 ( 30 per cent) \\
\hline & 102 & 75 (73.5 per cent) & $27(26.5$ per cent $)$ \\
\hline
\end{tabular}

between the age at which satisfactory and unsatisfactory results were obtained (Table VIII).

Primary open reduction and acetabuloplasty gave satisfactory results in fifty hips (77 per cent), secondary acetabuloplasty in seven hips (70 per cent) and primary acetabuloplasty alone in eighteen hips (67 per cent) (Table IX). A satisfactory result was obtained with homologous bone bank rib as graft material in forty-one hips (78 per cent) and with autologous iliac bone in twenty-three hips (65 per cent). Both materials were used in four hips, all of which were considered satisfactory (Table X).

Analysis of the radiological appearances showed that only nineteen hips (18.5 per cent) could be assessed as entirely normal by our criteria. Sixteen of these were in the excellent group and three in the good.

Conversely, fifteen hips assessed as excellent showed some radiological blemish, of which the commonest was coxa magna (seven hips). Forty-four hips classified as good showed significant coxa magna in twenty. The C.E. angle (Wiberg 1939) was never below 20 in the excellent group but was below 20 in fifteen of those rated as good. No hip rated as unsatisfactory had a normal radiological appearance.

\section{COMPLICATIONS}

In seventeen hips (17 per cent) stability was not maintained. In three of these two further stabilising procedures were performed. Redisplacement sometimes occurred soon after operation, when an open reduction and perhaps a second acetabuloplasty were required. Alternatively it occurred slowly over a period of years (up to a maximum of thirteen) and was then treated in a variety of ways. Repeat acetabuloplasty, innominate osteotomy (Salter 1961), pelvic osteotomy (Chiari 1955), classical shelf operation and arthrodesis were all employed in these later cases.

Epiphysitis was specifically recorded as occurring in only six hips after operation. However, it is difficult accurately to define this complication as is shown by the wide variation of its recorded occurrence by other authors (Gill 1948; Massie 1957; MacKenzie, Seddon and Trevor 1960; Salter 1961; Scaglietti and Calandriello 1962).

A considerable number of hips showed radiological stigmata of epiphysitis after closed or operative treatment before acetabuloplasty. After operation only thirty-one hips (30 per cent) had femoral heads which could be assessed as normal on radiological grounds.

TABLE $X$

Results Related to Type of Graft

\begin{tabular}{|c|c|c|c|c|c|c|c|}
\hline \multirow[b]{2}{*}{ Operation } & \multirow{2}{*}{$\begin{array}{l}\text { Number } \\
\text { of hips }\end{array}$} & \multicolumn{2}{|c|}{ Autologous iliac bone } & \multicolumn{2}{|c|}{ Homologous bone bank rib } & \multicolumn{2}{|c|}{$\begin{array}{l}\text { Combination of autologous } \\
\text { iliac bone and bone bank rib }\end{array}$} \\
\hline & & Satisfactory & Unsatisfactory & Satisfactory & Unsatisfactory & Satisfactory & Unsatisfactory \\
\hline $\begin{array}{l}\text { Primary open } \\
\text { reduction and } \\
\text { acetabuloplasty }\end{array}$ & 65 & $\begin{array}{c}13 \\
\text { (68.4 per cent) }\end{array}$ & $\begin{array}{c}6 \\
\text { (31.6 per cent) }\end{array}$ & $\begin{array}{c}36 \\
\text { (80 per cent) }\end{array}$ & $\begin{array}{c}9 \\
\text { (20 per cent) }\end{array}$ & 1 & $\mathbf{0}$ \\
\hline $\begin{array}{l}\text { Primary } \\
\text { acetabuloplasty }\end{array}$ & 27 & $\begin{array}{c}10 \\
(58 \cdot 8 \text { per cent })\end{array}$ & $\stackrel{7}{(41 \cdot 2 \text { per cent })}$ & $\begin{array}{c}5 \\
(71 \cdot 4 \text { per cent })\end{array}$ & $\stackrel{2}{2}$ & 3 & 0 \\
\hline $\begin{array}{l}\text { Secondary } \\
\text { acetabuloplasty }\end{array}$ & 10 & $\begin{array}{c}3 \\
\text { (75 per cent) }\end{array}$ & $\stackrel{1}{(25 \text { per cent })}$ & $\stackrel{4}{\quad}$ & $\stackrel{2}{2}$ & $\mathbf{0}$ & 0 \\
\hline & 102 & $\begin{array}{c}26 \\
(65 \text { per cent })\end{array}$ & $\begin{array}{c}14 \\
(35 \text { per cent })\end{array}$ & $\begin{array}{c}45 \\
(77.6 \text { per cent })\end{array}$ & $\begin{array}{c}13 \\
(22 \cdot 4 \text { per cent })\end{array}$ & 4 & 0 \\
\hline
\end{tabular}




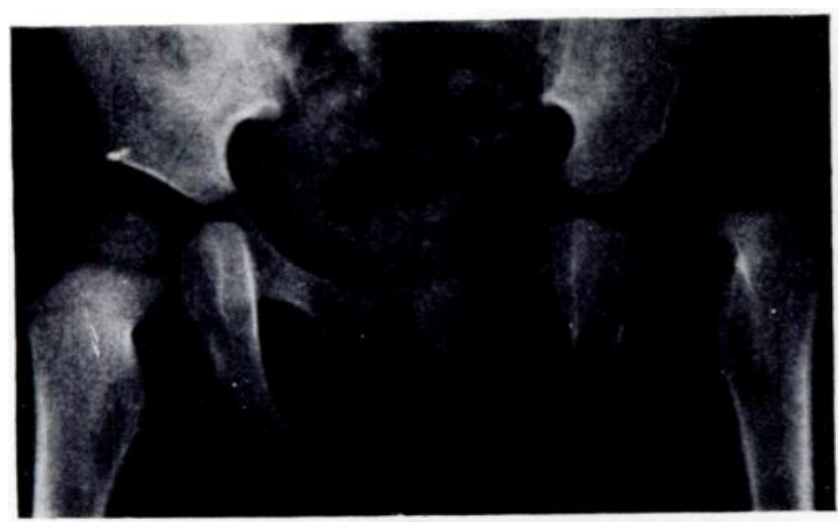

Fig. 6

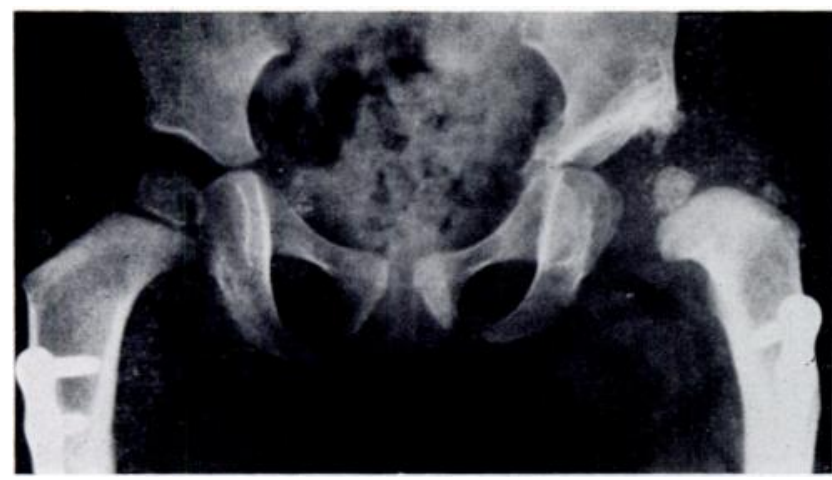

Fig. 7

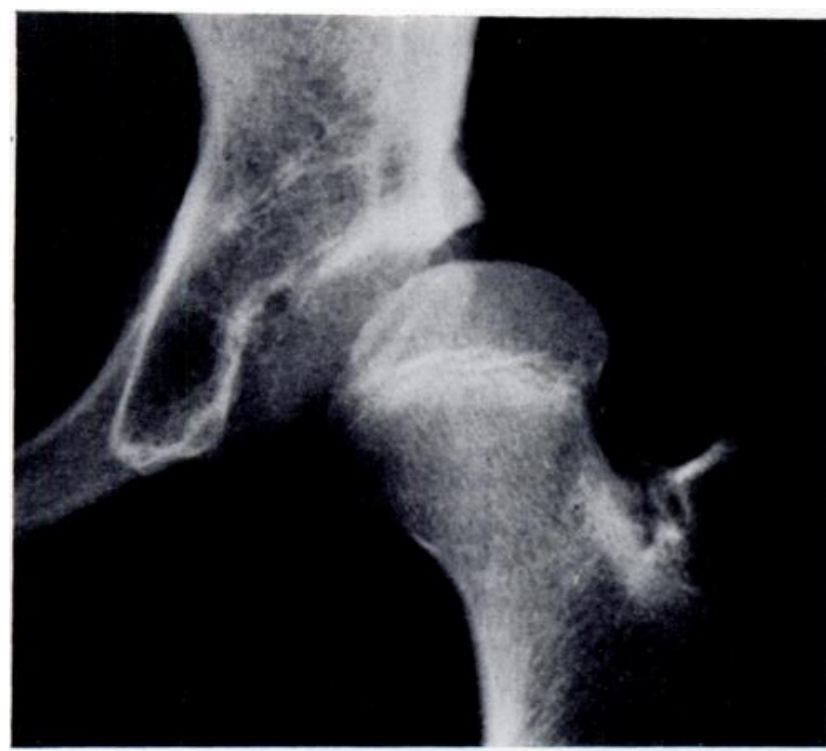

Fig. 8

Radiographs showing initial dislocation and results of inadequate concentric reduction.

Supracondylar fracture of the femur occurred several times after removal of the hip spica. One femoral osteotomy failed to unite and was treated by bone grafting. One patient died after open reduction for early redisplacement.

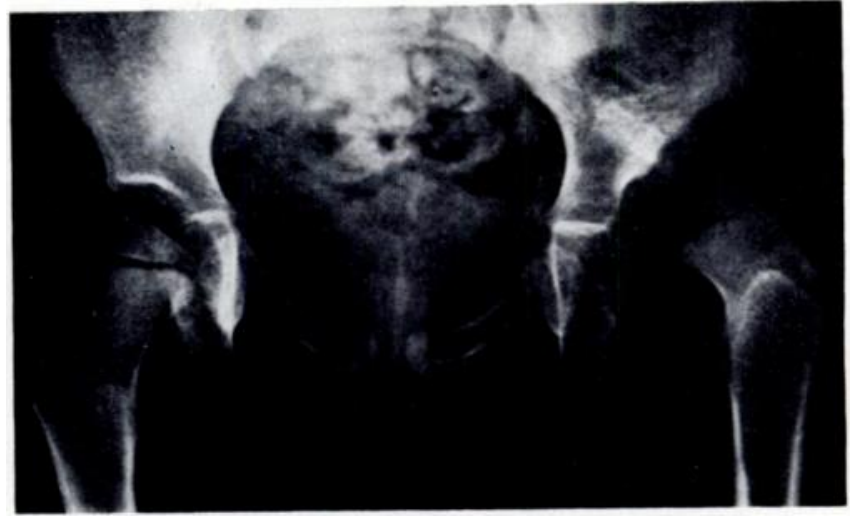

Fig. 9

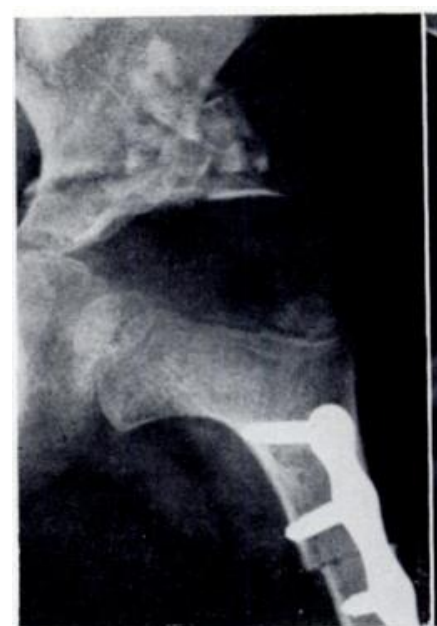

Fig. 10

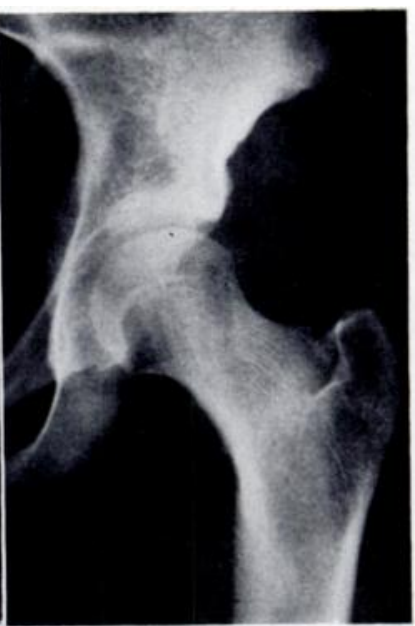

FIG. 11
Radiographs showing good result in an older child. Note concentric reduction.

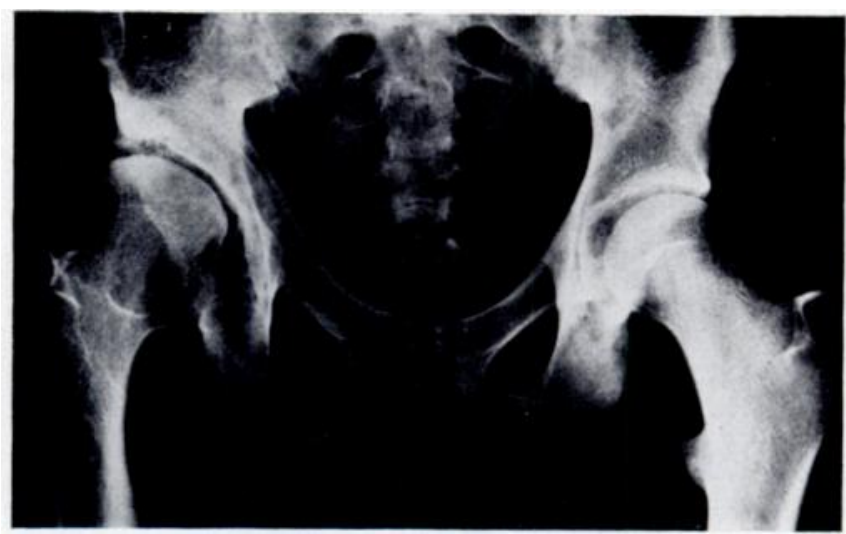

FIG. 12

Coxa magna occurring after concentric reduction and acetabuloplasty.

\section{DISCUSSION}

The operation performed on these patients was similar to that ascribed to A. O. Parker of Cardiff in that the acetabular roof was levered down over the femoral head 
and held in place by a graft (Figs. 4 and 5). Preserved homologous rib graft appears to be more effective than autologous iliac bone in supporting the acetabular reconstruction. This is probably related to the predominantly cortical nature of the rib graft as compared with iliac bone, which is mainly cancellous. The ribs were removed during procedures on scoliotic patients and were stored in a bone bank. They were incorporated rapidly and completely. By contrast, in several cases in which autologous iliac bone was used, progressive collapse of the graft occurred with late failure of the reconstruction.

An important feature which emerges from the study is that concentric reduction of the femoral head is vital if a satisfactory result is to be achieved. In patients where significant subluxation persisted acetabular reconstruction acted simply as a shelf and was inadequate to maintain stability (Figs. 6 to 8 ). This conclusion is supported by the figures in Table IX, which show that improved results were obtained when acetabuloplasty was accompanied or preceded by open reduction. A disturbing feature of the study is the steady deterioration in the quality of results with time (Table VII). This seems to be related to those patients in whom concentric reduction was not achieved and stability was not maintained. It is notable that fifteen out of forty-four hips classified as good at follow-up had a C.E. angle of less than 20. This was considered definitely abnormal by Wiberg and it seems probable that these are hips which will deteriorate with time.

There was no apparent difference between the average age at which satisfactory and unsatisfactory results were obtained (Table VIII). Good results were obtained in children up to the age of nine or ten years and bad results in children of two or three. This is disappointing as it was hoped that early operation would allow more time for moulding of the reconstructed socket to the femoral head. By contrast, it appears that a good result can be expected even in late childhood provided that the reduction of the dislocated or subluxed hip is concentric (Figs. 9 to 11 ).

Radiological criteria are more strict than either clinical observation or the patient's subjective assessment. Many hips which scored good or excellent results on clinical grounds showed considerable radiological abnormality. Only nineteen hips ( 18.5 per cent) could be considered radiologically entirely normal (Fig. 11).

Coxa magna was the commonest abnormality (Fig. 12). It was frequently consistent with an otherwise good or excellent result. This deformity is presumably related to vascular changes associated with the operative procedures around the hip joint.

Failure to maintain stability in 17 per cent is unsatisfactory. The early redisplacements were largely due to technical problems especially when acetabuloplasty was performed in hips which had undergone previous conservative and operative attempts at stabilisation. After a replacement many of these achieved satisfactory results but were considered for the purposes of this study as failures. The later redisplacements seem once again to demonstrate failure of concentric reduction or could be ascribed to graft collapse particularly where iliac bone was used.

The incidence of epiphysitis differs widely among various authors. Gill (1948) thought that open reduction always produced some abnormality. Massie (1951) quoted 55 per cent; MacKenzie, Seddon and Trevor (1960) 33.3 per cent; and Salter (1961) 4 per cent. In our patients a considerable number of hips had radiological changes indicative of epiphysitis before acetabuloplasty and only 30 per cent had normal femoral heads when followed up. If abnormality of head shape is considered to be indicative of epiphysitis this gives an incidence of 70 per cent, whereas on clinical grounds epiphysitis was recorded in only six patients or 7 per cent.

We would like to thank the Medical Records and Photographic Departments at the Royal National Orthopaedic Hospital and the Medical Illustrations Department of St Bartholomew's Hospital for their valuable assistance in the preparation of this paper.

\section{REFERENCES}

Chiari, K. (1955) Ergebnisse mit der Beckenosteotomie als Pfannendachplastik. Zeitschrift für Orthopädie und ihre Grenzgebeite, 87, 14-26. Gill, A. B. (1948) The end results of early treatment of congenital dislocation of the hip. Journal of Bone and Joint Surgery, 30-A, 442-453. MacKenzie, I. G., Seddon, H. J., and Trevor, D. (1960) Congenital dislocation of the hip. Journal of Bone and Joint Surgery, 42-B, 689-705. Massie, W. K. (1951) Vascular epiphyseal changes in congenital dislocation of the hip. Journal of Bone and Joint Surgery, 33-A, 284-304. Salter, R. B. (1961) Innominate osteotomy in the treatment of congenital dislocation and subluxation of the hip. Journal of Bone and Joint Surgery, 43-B, 518-539.

Scaglietti, O., and Calandriello, B. (1962) Open reduction of congenital dislocation of the hip. Journal of Bone and Joint Surgery, 44-B, 257-283.

Smith-Petersen, M. N. (1949) Approach to and exposure of the hip joint for mold arthroplasty. Journal of Bone and Joint Surgery, 31-A, 40-46.

Trevor, D. (1972) Congenital dislocation of the hip. Annals of the Royal College of Surgeons of England, 50, $213-237$.

Wiberg, G. (1939) Studies on dysplastic acetabula and congenital subluxation of the hip joint with special reference to the complication of osteoarthritis. Acta chirurgica Scandinavica, 83, Supplementum 58. 